\title{
Stabilizing crop productivity returns and soil improvement by agroforestry practices under marginal lands in semi-arid tropics of Telangana state, India
}

A. KRISHNA, M.A. AARIFF KHAN AND B. JOSEPH

Received : 30.09.2017; Revised : 10.11.2017; Accepted : 20.11.2017

MEMBERS OF RESEARCH FORUM:

Corresponding author : A. KRISHNA, Department of Agronomy, AICRP on Agroforestry, Professor Jayashankar Telangana State Agricultural University, Rajendranagar, HYDERABAD, (TELANGANA) INDIA
Co-authors :

M.A. AARIFF KHAN, Department of Soil Science,AICRP on Agroforestry, Professor Jayashankar Telangana State Agricultural University, Rajendranagar, HYDERABAD, (TELANGANA) INDIA

B. JOSEPH, Department of Agronomy, College of Agriculture, Palem, NAGARKURNOOL (TELANGANA) INDIA

\section{Summary}

Different agroforestry trials conducted in Agroforestry Research blocks, Professor Jayashankar Telangana State Agricultural University, Hyderabad has showed higher economic gain in marginal lands. Sunflower grown when inter cropped in Hardwickia binata after stylo recorded higher seed yield (342 $\left.\mathrm{kg} \mathrm{ha}^{-1}\right)$ than grown after fallow in Hardwickia binata $\left(248 \mathrm{~kg} \mathrm{ha}^{-1}\right)$. The net returns from tree and crop were considerably higher when sunflower grown as inter crop in Hardwickia binata Rs. $6593 \mathrm{ha}^{-1}$. The Faidherbia albida (13 years age old) trial revealed that seed yield of maize + soybean when grown as inter crop was higher $\left(2.94 \mathrm{t} \mathrm{ha}^{-1}\right)$ when compared to sole cropped maize without trees $\left(1.7 \mathrm{t} \mathrm{ha}^{-1}\right)$. Due to shade effect of tamarind, after 8 years the same system was converted to horti-horti system for better land utilization by planting economic demand plants such as henna. The higher fresh biomass production of henna $\left(640 \mathrm{~kg} \mathrm{ha}^{-1}\right)$ recorded in double row planting when compared to single row. The soil productivity and fertility was improved in degraded marginal lands by different agroforestry practices. Pertaining to soil improvement over initial in different agroforestry practices the influence of different land use systems on soil properties and nutrient status revealed that bulk density reduced in surface and sub-surface soil in all tree based systems as compared to fallow (1.65 and $1.68 \mathrm{mg} \mathrm{m}^{-3}$ ) and agricultural lands. The water holding capacity and infiltration rate was maximum in agri-horti system 30.0 and 30.0 per cent at $0-15$ and $15-30 \mathrm{~cm}$ depth, respectively. Nutrient status and organic carbon was more in soils with tree plantation. Soil enrichment found in marginal lands in different agroforestry practices such as Melia azedarach based agri-silvi system, the conjoint use of $75 \% \mathrm{RD} \mathrm{N}+25 \% \mathrm{~N}$ poultry manure showed significant effect on OC $(0.59 \%)$ and available NPK $\left(150.0,24.95,210.0 \mathrm{~kg} \mathrm{ha}^{-1}\right)$ followed by $100 \% \operatorname{RDF}\left(0.55 \%\right.$ and $\left.147.0,24.00,216.0 \mathrm{~kg} \mathrm{ha}^{-1}\right)$. In case of Melia dubia based silvi-pasture system, the $\mathrm{OC}$ and available $\mathrm{N}$ and $\mathrm{P}$ significantly affected by type of fodders and nutrient management over farmers practice i.e. FYM $10 \mathrm{t} \mathrm{ha}^{-1}$. But there is no significant effect by interactions. The highest OC content recorded in fodder maize $(0.52 \%)$ than sorghum $(0.46 \%)$. In case of available $\mathrm{N}$ and $\mathrm{P}$ the significant effect found with fodder sorghum (152.0 and 51.00 $\mathrm{kg} \mathrm{ha}^{-1}$ ) than maize (109 and $\left.22.42 \mathrm{~kg} \mathrm{ha}^{-1}\right)$.

Key words : Agroforestry practices, Soil improvement, Tree crop relation 